\title{
Acute Toxicity (Lethal Dose 50 Calculation) of Herbal Drug Somina in Rats and Mice
}

\author{
Muhammad Ahmed \\ Department of Pharmacology and Toxicology, Faculty of Pharmacy, Umm Al-Qura University, Makkah, \\ Kingdom of Saudi Arabia \\ Email: hma00ahmed@hotmail.com
}

Received 1 January 2015; accepted 17 March 2015; published 23 March 2015

Copyright (C) 2015 by author and Scientific Research Publishing Inc.

This work is licensed under the Creative Commons Attribution International License (CC BY).

http://creativecommons.org/licenses/by/4.0/

(c) (i) Open Access

\section{Abstract}

Somina (herbal preparation) prepared by Hamdard Laboratories (Waqf) Pakistan is a mixture of five different medicinal plants, widely prescribed for the treatment of mental illness. For acute toxicity, the Karber arithmetic method for the calculation of LD50 and Hodge and Sterner toxicity scale was used. In this study, different doses $(10,100,285,500,1000,5000$ and $10,000 \mathrm{mg} / \mathrm{kg})$ of the extract was administered orally to the different groups of rats and mice. Signs of toxicity and possible death of animals were monitored for $24 \mathrm{hrs}$ to calculate the median lethal dose (LD50) of somina. At the end of the study, all the animals in all the dose groups were sacrificed and the internal organ-body was compared with values from the control group. The LD50 was found to be $>10,000$ $\mathrm{mg} / \mathrm{kg}$ body weight upon oral administration in mice and rats as no mortality was observed after single dose administration. According to Hodge and Sterner toxicity scale, the obtained value of LD $50>10,000 \mathrm{mg} / \mathrm{kg}$ classified the Somina as Practically non-toxic herbal medicine.

\section{Keywords}

Acute Toxicity, Somina, Median Lethal Dose (LD50), Karber Arithmetic Method for the Calculation of LD50, Hodge and Sterner Toxicity Scale

\section{Introduction}

Somina (Herbal drug) prepared by Hamdard Laboratories (Waqf) Pakistan in powdered form is widely used in Unani system of medicine for the treatment of mental illness. It is claimed that somina possesses sedative, hypnotic and anxiolytic activities [1]. Somina is composed of five different medicinal plants.

Sesamum indicum, Prunus amygdalus, Papaver somniferum, Lactuca serriola (seed extracts), Lagenaria vulgaris. 
In the literature, different properties of these medicinal plants have been reported. Sesamum indicum was reported to have antioxidant [2] and anti-inflammatory activities [3]. Prunus amygdalus keeps medicinal properties such as anti-inflammatory, sedative, anti-hyperlipidemia, antitumor and antioxidant and Antimicrobial [4]. Anticonvulsant [5] and analgesic activity [6] of Papaver somniferum were cited in the literature. Lactuca serriola was found to possess spasmogenic, spasmolytic, bronchodilator, and vasorelaxant activities [7]. Since ancient times Lagenaria vulgaris has been utilized for treatment of jaundice, diabetes, ulcer, piles, colitis, hypertension and skin diseases [8]. Despite the popular use of these plants, some toxicological studies have previously performed and the results showed that at different doses Lagenaria vulgaris (2 g/kg: [9]), Lactuca serriola (6 g/kg; [10]), Prunus amygdalus (2 g/kg: [11]), Sesamum indicum (500 mg/kg: [12]) were found to be well tolerated. However, toxicity or safety of Individual constituents has reported in the literature but screening has not yet done on somina as whole to confirm its safety for the use in folkloric medicine. This study was conducted to investigate the toxicity of somina having all ingredients together.

\section{Materials and Methods}

\subsection{Formation of Different Doses of Somina}

Somina is available in powder form. Recommended dose of somina for human is $10 \mathrm{~g} / 70 \mathrm{~kg}$. In the present study, different doses of somina were used as shown in Table 1.

All doses were prepared by dissolving its powder in distilled water at the time of administration for the determination of LD50.

\subsection{Animals}

40 Adult NMRI mice (20 - 25 g) and 40 adult Sprague-Dawley Rats (200 - 250 g) of either sex were obtained from Dr. Hafiz Muhammad Ilyas Institute of Pharmacology and Herbal Sciences (Dr. HMIIPHS) and were housed in groups of 5 per cage for seven days prior to experimentation in an ideal laboratory environment as per OCED [13]. Each experimental group consisted of five animals. University and Departmental committee for Research and Ethics had approved all the experimental protocols. Each animal was used only once. For ethical reason, all animals were sacrificed at the end of the study [14].

\subsection{Toxicological/Safety Evaluation Studies in Mice}

Eight groups containing five NMR-I mice (25 - $30 \mathrm{~g}$ ) in each and eight groups containing five rats (200 - $250 \mathrm{~g}$ ) were used in this study. All animals were treated orally once and different doses (control, 10, 100, 285, 500, 1000, 5000, 10,000 mg/kg) were administered as shown in Table 1.

Animals were weighed before the dose administration. All the animals were kept under continuous observation for 6 hours after the administration of the dose, for any change in behavior or physical activities. After 24 hrs, all survived mice were anesthetized with pentothal sodium $(40 \mathrm{mg} / \mathrm{kg})$ and autopsied.

Table 1. Different doses of somina (herbal drug).

\begin{tabular}{ccc}
\hline S. No. & Dose & Ratio \\
1 & $10 \mathrm{mg} / \mathrm{kg}$ & Less than human dose \\
2 & $100 \mathrm{mg} / \mathrm{kg}$ & Approximately similar to human dose \\
3 & $285 \mathrm{mg} / \mathrm{kg}$ & 2 times greater than human dose \\
4 & $500 \mathrm{mg} / \mathrm{kg}$ & 4 time greater than human dose \\
5 & $1000 \mathrm{mg} / \mathrm{kg}$ & 7 time greater than human dose \\
6 & $5000 \mathrm{mg} / \mathrm{kg}$ & 35 time greater than human dose \\
7 & $10,000 \mathrm{mg} / \mathrm{kg}$ & 70 time greater than human dose \\
8 & Saline $(10 \mathrm{ml} / \mathrm{kg})$ & Control group
\end{tabular}




\subsection{Calculation of Median Lethal Dose (LD50)}

For each mouse, the observation was made for $24 \mathrm{hr}$ and symptoms of toxicity and rate of mortality in each group were noted. At the end of study period, expired animals were counted for the calculation of LD50. The arithmetic method of Karber [15] was used for the determination of LD50.

$$
\mathrm{LD} 50=\mathrm{LD} 100-\Sigma(a \times b) / n
$$

$n=$ total number of animal in a group.

$a=$ the difference between two successive doses of administered extract/substance.

$b=$ the average number of dead animals in two successive doses.

LD100 $=$ Lethal dose causing the $100 \%$ death of all test animals.

Hodge and Sterner scale (Table 2) was used for the evaluation of toxicity with the help of LD50 [16].

\section{Results}

From the experiment, the results reveal that the somina has not been found to be toxic even at $10,000 \mathrm{mg} / \mathrm{kg}$ or $10 \mathrm{mg} / \mathrm{kg}$ that is 70 times higher than the human dose in experimental animals (rats and mice) as shown in Table 3 . The animals received $10,000 \mathrm{mg} / \mathrm{kg}$ orally was not found to cause any mortality and non-significant changes were observed in wellness parameters used for evaluation of toxicity. Behavioral pattern like salivation, sleep cycle and corner sitting of the treated animals were found to enhance (Table 3). However, the low doses did not produce any pronounced effect. Autopsy revealed that no changes were observed in organ structure and weight.

Table 2. Hodge and sterner toxicity scale.

\begin{tabular}{ccc}
\hline S. No. & Term & LD50 (Rat, Oral) \\
\hline 1 & Extremely Toxic & Less than $1 \mathrm{mg} / \mathrm{kg}$ \\
2 & Highly Toxic & $1-50 \mathrm{mg} / \mathrm{kg}$ \\
3 & Moderately Toxic & $50-500 \mathrm{mg} / \mathrm{kg}$ \\
4 & Slightly Toxic & $500-5000 \mathrm{mg} / \mathrm{kg}$ \\
5 & Practically Non-Toxic & $5000-15,000 \mathrm{mg} / \mathrm{kg}$ \\
\hline
\end{tabular}

Table 3. Toxicological study of different doses of somina administered orally in mice and rats.

\begin{tabular}{|c|c|c|c|c|}
\hline S. No. & Groups & Dose/Day & Mortality (x/N) & Symptoms (2 hr) \\
\hline \multicolumn{5}{|c|}{ Toxicity in Mice } \\
\hline 1 & Group I & Saline $(10 \mathrm{ml} / \mathrm{kg})$ & $0 / 5$ & Nil \\
\hline 2 & Group II & $10 \mathrm{mg} / \mathrm{kg}$ & $0 / 5$ & Nil \\
\hline 3 & Group III & $100 \mathrm{mg} / \mathrm{kg}$ & $0 / 5$ & Nil \\
\hline 4 & Group IV & $285 \mathrm{mg} / \mathrm{kg}$ & $0 / 5$ & Nil \\
\hline 5 & Group V & $500 \mathrm{mg} / \mathrm{kg}$ & $0 / 5$ & Nil \\
\hline 6 & Group VI & $1000 \mathrm{mg} / \mathrm{kg}$ & $0 / 5$ & Nil \\
\hline 7 & Group VII & $5000 \mathrm{mg} / \mathrm{kg}$ & $0 / 5$ & Corner Sitting, \\
\hline 8 & Group VIII & $10,000 \mathrm{mg} / \mathrm{kg}$ & $0 / 5$ & Corner Sitting, Salivation, Drowsy \\
\hline \multicolumn{5}{|c|}{ Toxicity in Rats } \\
\hline 1 & Group I & Saline $(10 \mathrm{ml} / \mathrm{kg})$ & $0 / 5$ & Nil \\
\hline 2 & Group II & $10 \mathrm{mg} / \mathrm{kg}$ & $0 / 5$ & Nil \\
\hline 3 & Group III & $100 \mathrm{mg} / \mathrm{kg}$ & $0 / 5$ & Nil \\
\hline 4 & Group IV & $285 \mathrm{mg} / \mathrm{kg}$ & $0 / 5$ & Nil \\
\hline 5 & Group V & $500 \mathrm{mg} / \mathrm{kg}$ & $0 / 5$ & Nil \\
\hline 6 & Group VI & $1000 \mathrm{mg} / \mathrm{kg}$ & $0 / 5$ & Nil \\
\hline 7 & Group VII & $5000 \mathrm{mg} / \mathrm{kg}$ & $0 / 5$ & Corner Sitting, Palpeberalptosis \\
\hline 8 & Group VIII & $10,000 \mathrm{mg} / \mathrm{kg}$ & $0 / 5$ & Corner Sitting, Salivation, Palpeberalptosis, Drowsy \\
\hline
\end{tabular}


LD50 Value: As per observations and calculations (Karber, 1931), the LD50 value of somina after oral administration was found to be more than $10,000 \mathrm{mg} / \mathrm{kg}$ body weight.

According to Hodge and Sterner (2005) toxicity scale, somina is said to be in non-toxic herbal drug category (Table 2).

\section{Discussion}

Although, the somina is used in folkloric medicine for the treatment of mental illness and research had been done to investigate its said effect [1] [17] but the present study was conducted to reveals the safety evaluation of somina, because it contain different constituent and it is a mixture of five medicinal plants. However, each plant contains different active compounds have medicinal and toxic effects. That's why it is mandatory to evaluate the toxicity of herbal drugs (somina) whose adverse effects and toxic doses are mostly unknown [18]. Previously reported data revealed the toxic effect of different herbs at different doses such as Kava, germander (Teucriumchamaedrys). Chaparral (Larrea tridentate) causes severe liver injury [19]. Licorice can induce hypokalemic myopathy [20] and Kelp (seaweed) can cause hyperthyroidism [21]. In the present study, the somina was found to be safe up to $10,000 \mathrm{mg} / \mathrm{kg}$ orally.

This present study is in agreement with other previous studies in which different doses of constituent of somina is reported to be safe like Lagenaria vulgaris at the dose of $2 \mathrm{~g} / \mathrm{kg}$ [9], Lactuca serriola at the dose of 6 $\mathrm{g} / \mathrm{kg}$ [10], Prunus amygdalus at the dose of $2 \mathrm{~g} / \mathrm{kg}$ [11], while Sesamum indicum did not produce any toxicity up to the dose of $500 \mathrm{mg} / \mathrm{kg}$ [12]. In the present study, a maximum dose of somina was used in all above of reported literature doses were less than the present study. Although the present study confirms that somina is practically non-toxic [16]. In the present study, other organs like kidney, heart and spleen did not show any significant change.

\section{Conclusion}

In conclusion, the results of the present study conclude that somina is safe or practically non-toxic when administered orally. This study is the preliminary study; in the future, this research is offering an outset to continue the research by administering the somina through different routes in different animals' species and in human.

\section{Acknowledgements}

Author is grateful to Prof. S. I Ahmed (Late) Former Dean Faculty of Pharmacy, University of Karachi, Hamdard University Karachi and Director of HMIIPHS, Hamdard University Karachi for his support, encouragement at every step of this study and Hamdard Foundation Pakistan for financial support.

\section{Ethical Approval}

Author hereby declared that the experimental protocol was approved by the University and Departmental committee for Research and Ethics. Each animal was used only once. For ethical reason, all animals were sacrificed at the end of the study (AVMA Guideline, 2013). Experimental protocol was followed according to Guidelines for Care and Use of Laboratory Animals in Biomedical Research (2010). All rules were followed as well as specific national laws where applicable.

\section{Competing Interests}

The author has no conflict of interest to report.

\section{References}

[1] Azmat, A., Ahmed, M., Zafar, N. and Ahmad, S.I. (2008) Neuropharmacological Profile of Somina (Herbal Drug) in Mice and Rats. Pakistan Journal of Pharmacology, 25, 53-58.

[2] Hu, Q., Xu, J., Chen, S. and Yang, F. (2004) Antioxidant Activity of Extracts of Black Sesame Seed (Sesamum indicum L.) by Supercritical Carbon Dioxide Extraction. Journal of Agricultural and Food Chemistry, 25, 943-947.

[3] Hsu, D., Chu, P.Y. and Liu, M.Y. (2012) Emerging Trends in Dietary Components for Preventing and Combating Disease. Sesame Seed (Sesamum indicum L.) Extracts and Their Anti-Inflammatory Effect. American Chemical Society ACS Symposium Series, 1093, 335-341. http://dx.doi.org/10.1021/bk-2012-1093.ch019 
[4] Thebo, N., Sheikh, W., Bhangar, M.I., Iqbal, P. and Nizamani, M.H. (2012) Therapeutic and Antioxidant Potential in the Shell Extract of Prunus amygdalus against Dermal Mycosis. Medicinal \& Aromatic Plants, 1, 108. http://dx.doi.org/10.4172/2167-0412.1000108

[5] Heidari, M.R. and Bayat, M. (2003) Effect of Methanol Extract of Papaver somniferum L. on Seizure Induced by Picrotoxin in Male Mice. Journal of Rafsanjan University of Medical Sciences and Health Services, 2, 187-194.

[6] Calixto, J.B., Scheidt, C., Otuki, M. and Santos, A.R. (2001) Biological Activity of Plant Extracts: Novel Analgesic Drugs. Expert Opinion on Emerging Drugs, 6, 261-279. http://dx.doi.org/10.1517/14728214.6.2.261

[7] Janbaz, K.H., Latif, M.F., Saqib, F., Imran, I., Zia-Ul-Haq, M. and De Feo, V. (2013) Pharmacological Effects of Lactuca serriola L. in Experimental Model of Gastrointestinal, Respiratory, and Vascular Ailments. Evidence-Based Complementary and Alternative Medicine, 2013, Article ID: 304394, 9 p. http://dx.doi.org/10.1155/2013/304394

[8] Prajapati, R.P., Kalariya, M., Parmar, S.K. and Sheth, N.R. (2010) Phytochemical and Pharmacological Review of Lagenaria sicereria. Journal of Ayurveda and Integrative Medicine, 1, 266-272. http://dx.doi.org/10.4103/0975-9476.74431

[9] Saha, P., Mazumder, U.K., Haldar, P.K., Islam, A. and Kumar, S.R.B. (2011) Evaluation of Acute and Sub Chronic Toxicity of Lageneria seceraria Aerial Parts. International Journal of Pharmaceutical Sciences and Research, 2.

[10] Sayyah, M., Hadidi, N. and Kamalinejad, M. (2004) Analgesic and Anti-Inflammatory Activity of Lactuca sativa Extract in Rats. Journal of Ethnopharmacology, 92, 325-329. http://dx.doi.org/10.1016/j.jep.2004.03.016

[11] Shah, K.H., Patel, J.B., Shrma, V.J., Shrma, R.M., Patel, R.P. and Chaunhan, U.M. (2011) Evaluation of Antidiabetic Activity of Prunus amygdalus Batsch in Streptozotocin Induced Diabetic Mice. The Research Journal of Pharmaceutical, Biological and Chemical Sciences, 2, 429-434.

[12] Palanisamy, B. and Shanmugasundaram, K. (2012) Acute and Subacute Oral Toxicity Studies of Ethanolic Extract of Sesamum indicum Seeds (Linn.) in Winstar Albino Rats. Journal of Global Pharma Technology, 4, 17-23.

[13] OECD (2001) Guidelines for Testing of Chemicals. Acute Oral Toxicities up and down Procedure. 425, 1-26. www.oecd.org/dataoecd/17/51/1948378.pdf

[14] AVMA Guidelines for the Euthanasia of Animals: 2013 Edition.

[15] Karber, G. (1931) Beitrag zur kollecktiven Behandlung pharmakologischer Reihenversuche. Arch. Exptl. Pathol. Pharmakol, 162, 480-483.

[16] Hodge, A. and Sterner, B. (2005) Toxicity Classes. In: Canadian Center for Occupational Health and Safety. http://www.ccohs.ca/oshanswers/chemicals/id50.htm

[17] Azmat, A., Ahmed, M., Haider, S., Haleem, D.J., Zafar, N. and Ahmad, S.I. (2012) Enhanced Memory Processes under the Influence of Herbal Drug Somina and Its Effect on Brain Serotonin. African Journal of Pharmacy and Pharmacology, 6, 2458-2463. http://dx.doi.org/10.5897/AJPP11.612

[18] Elvin-Lewis, M. (2001) Should We Be Concerned about Herbal Remedies. Journal of Ethnopharmacology, 75, 141164. http://dx.doi.org/10.1016/S0378-8741(00)00394-9

[19] Stickel, F., Egerer, G. and Seitz, H.K. (2000) Hepatotoxicity of Botonicals. Public Health Nutrition, 3, 113-124. http://dx.doi.org/10.1017/S1368980000000161

[20] Shintani, S., Murase, H., Tsukagoshi, H. and Shiigai, T. (1992) Glycyrrhizin (Licorice)-Induced Hypokalemic Myopathy: Report of 2 Cases and Review of the Literature. European Neurology, 32, 44-51. http://dx.doi.org/10.1159/000116786

[21] Clark, C.D., Bassett, B. and Burge, M.R. (2003) Effect of Kelp Supplementation on Thyroid Function in Euthyroid Subjects. Endocrine Practice, 9, 363-369. http://dx.doi.org/10.4158/EP.9.5.363 